\title{
The Inclination toward Funding Cash Waqf-Based Education: Evidence From Kuwait Waqf Public Foundation
}

\author{
Meshari Al-Daihani
}

University of Malaya, Kuala Lumpur, Malaysia

meshari89.r@gmail.com

\begin{tabular}{ll}
\hline ARTICLE DETAILS \\
\hline History \\
Received $\quad$ : February \\
Revised Format $:$ March \\
Accepted : April \\
\hline
\end{tabular}

Keywords :

kuwait awqaf public foundation, waqf behavioral intention, education sector, theory of planned behavior.

\begin{abstract}
S
Kuwait Awqaf Public foundation plays a vital role in supporting Community development in Kuwait. However, it is undeniable that support for the educational forums by Kuwait Awqaf public foundation (KAPF) is significantly low graded compared to other distribution channels of Waqf. Besides, the literature that discussed the factors influencing behavioral intention to Waqf giving behavior is extremely limited in Kuwait. Therefore, this study aims to investigate the factors influencing behavral intention to endow to the education sector, particularly among the employees of Kuwait Awqaf public foundation (KAPF), based on the theory of planned behavior (TPB). A set of questionnaires was constructed to measure the validity of the theory in the field of Waqf giving behavior in Kuwait. This study found that all variables attitude, subjective norms, and perceived behavioral control were significantly related to intention to contribute to the education sector by Waqf in Kuwait.
\end{abstract}

(C2021 STIM Lasharan Jaya Makassar

\section{INTRODUCTION}

Education has always been an essential part of Sustainable Development (ESD) empowers people to change the way they think and work towards a sustainable future. The recent synthesis report of the UN Secretary-General on the post-2015 development agenda stated that "highquality education and life-long learning" and the capacity of teachers are key factors in empowering youth as a "globally connected engine for change" (Sachs, 2015). In line with that, Kuwait Government in their vision 2035 "New Kuwait" has defined education as a key to achieving economic development and social progress (Kuwait Vision 2035 "New Kuwait", 2018). The Kuwait Development Plan included several education focused projects including the Sabah Al-Salem University City which will accommodate the new campus of Kuwait University (Investment Opportunities in Kuwait through KDIPA, 2018).Yet, funding higher education institutions (HEIs) is a real dilemma and is deemed an outstanding issue in the cross the world. In Kuwait, the case becomes more complicated, especially if it is taken on consider that the small state depends only on oil-producing that is experiencing decline and fluctuate in the global market (The Economic Challenges Facing Kuwait and the Region, 2019). Therefore, the government has declared the highest deficit in the budget in its modern history (The General Budget The Fiscal Year 2019/2020, 2019).

In the landscape of HEIs, only one public university, the University of Kuwait, which continues to accommodate Kuwaiti nationals and residents. In addition, the Public Authority for Applied Education and Training (PAAET), which is a government-related entity that provides scholars with bachelor's degrees and diplomas. The head of the faculty members association at Kuwait University, Dr. Muhammad Al-Khader emphasized the absorptive capacity of the most prominent challenges facing higher education institutions, especially in a society in which the percentage of those under the age of 24 reaches $43 \%$ (Higher education 
between the challenges of reality and the aspirations of the future, 2019). On the other hand, the next available alternative for students is to attend one of the country's private universities. In fact, that the private universities in Kuwait do not offer higher education classes for a masters' degree and $\mathrm{PhD}$, while the University of Kuwait has a limited number of seats for those wishing to pursue any of those degrees.

To overcome the above-mentioned issues, students resort to study overseas because the price of studying certain majors in Kuwait can be as much as double the price of studying the same major abroad. At present, the number of Kuwaiti nationals is studying outside Kuwait exceeds 33,000. There are 12,000 Kuwaiti students pursuing their higher education in the United States: 8,500 in Egypt and approximately 6,000 in Jordan, as per the cultural attaché at the Kuwaiti embassy in the Hashemite Kingdom. There are also 4,000 Kuwaiti students attending one of the universities and higher education facilities in the U.K.; 3,000 in the UAE; 2,500 in Bahrain; 1,000 Kuwaitis studying in Australian universities; 600 in Ireland; 600 in Saudi Arabia; 200 in France, and 100 in Lebanon (Alelyan, 2019). However, in a pastoral country like Kuwait, where no tax and fees, the expenditure on education system constitute a burden on the public budget, especially in the current economic recession.

In the search for alternative sources of funding for higher education, the social finance model especially waqf represent an interesting option. Waqf plays a particularly important role in Muslim societies. It has grown steadily since its beginnings and has benefited the people and defrayed public expenses. Examples include the funding of mosques, graveyards, hospitals, schools, orphanages, warehouses, bakeries, mills and other charitable, educational, or religious foundations (Thaker, Thaker, \& Pitchay, 2018; Mahamood \& Ab Rahman, 2015). It has been used to support the aged and infirm; to provide relief for poverty; and even to take care of animals (Khaf, 1999; Zuki, 2012). All these instances of waqf were dedicated by their founders, irrespective of whether they were laymen or highly placed functionaries (Khaf, 1999; Thaker, Thaker, \& Pitchay, 2018). It has modelled a vital motion in the Islamic civilization in multiple community and financial dimensions.

Recently, roles of waqf become obvious and extend to other social purposes like education system, relief of poverty, take care of animals, agriculture, horticulture, and water resources (Mahamood \& Ab Rahman, 2015). The role of waqf in finance education system begins more robust a few decades ago both in the Muslim and non-Muslim countries. Even though these countries used different terms, they share a similar purpose with waqf which is contributing and collecting fund for good purposes to help the needy and at the same time aims to boost the standard living of the society. In Islamic countries, many educational institutions draw on waqf, in Egypt, Al-Azhar University, Al-Qurawiyin in Fez, Morocco; the University of Al-Muntasiriyyah, Iraq; the University of Cordova, Spain; the King Abdul Aziz University, Saudi Arabian; and the Islamic University of Indonesia (UII) (Zuki, 2012).

In Kuwait up to date, waqf is utilized only for religious purposes such as for building mosques, orphanages and for burial matters. The figures issued by (KAPF) in 2018 and 2019 respectively show that the waqf funds are directed to support education is limited. In 2018, for example, the percentage of waqf are directed to education was $(0.45 \%)$ from total waqf funds.

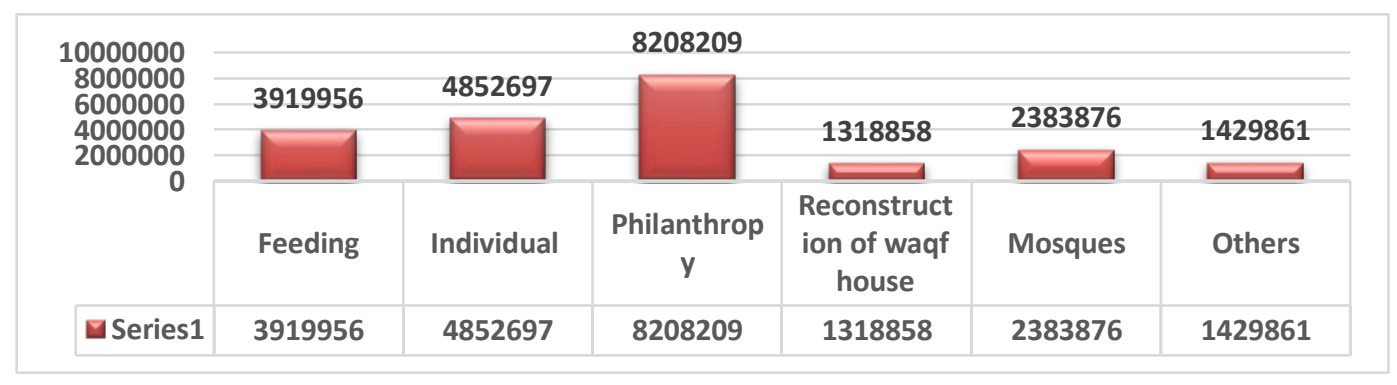


Distributions of waqf funds in 2019

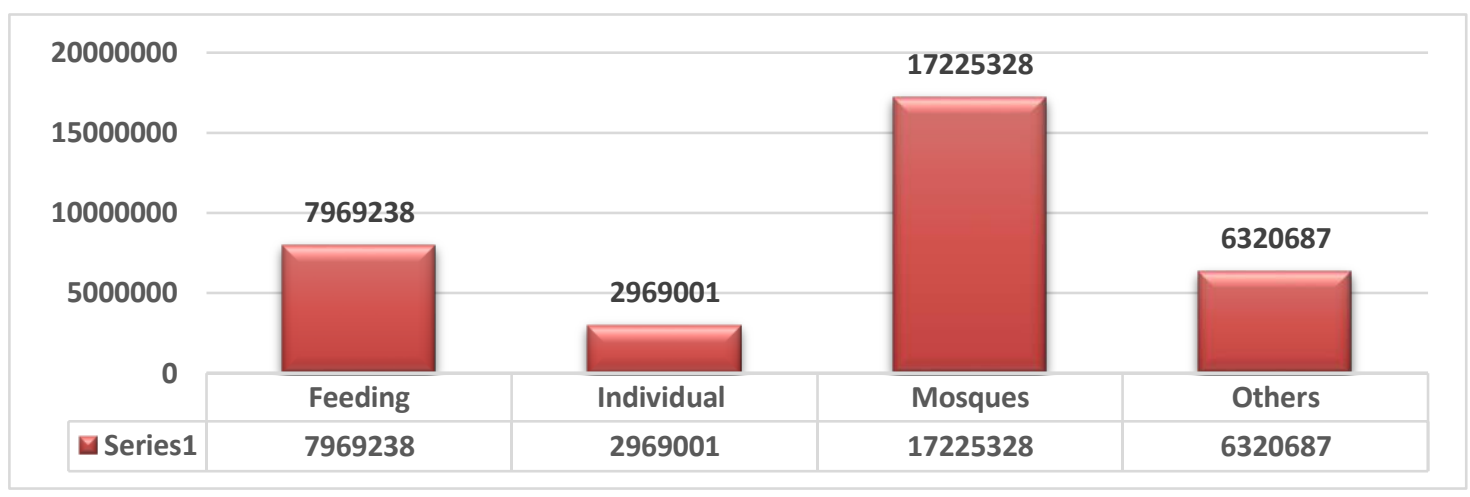

percentage of education from total waqf funds

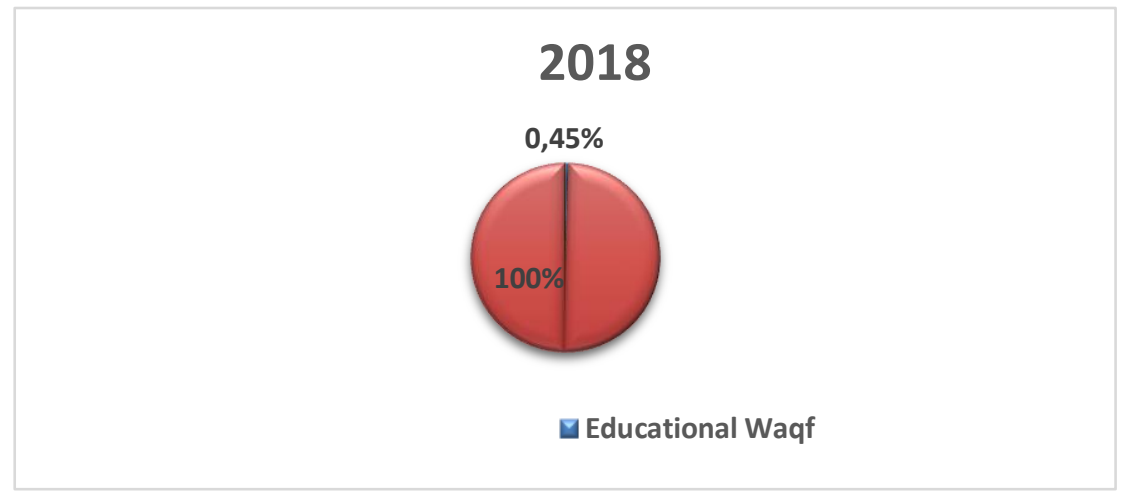

Notwithstanding, this shortcoming may be overcome by harnessing the potential of waqf (endowment). To the best knowledge of the researcher, there has been no research conducted about behavioral intention to donate waqf for education. The present study was intended to assess empirically behavioral intentions of donors/waqif to donate waqf for education sector. It is therefore expected that the key findings from this study, would be applicable to waqf institutions in Kuwait, and would benefit not only individuals, corporations and the country as a whole, but could also be adapted and validated for other nations as well.

\section{LITERATURE REVIEW AND HYPOTHESIS DEVELOPMENT}

The underpinning theory of this study is the TPB, which was developed by Ajzen (1985), 10 years after the development of the theory of reason action (Ajzen \& Fishbein, 1975). The theory stipulates that most human behavior is autonomous (Fishbein and Ajzen, 1975). Human behaviors are often influenced by behavioral intention, which is defined as the likelihood to act and the immediate determinant of a behavior (Ajzen, 1985). In TRA, the intention is a function of an individual's attitude towards the behavior and they believe that other people who are important to them think they should perform it Ajzen \& Fishbein, 1975). Many behaviors, however, are not always autonomous (Ajzen, 1991). This leads to one of TPB's most vital contributions: the inclusion of consumer's autonomous control on his/her decision making - perceived behavioral control. In summary, the theory stipulates that behavioral intention is determined by attitude, subjective norms, and perceived behavioral control. Thus, in the subsequent paragraphs, each of these identified constructs is discussed and hypotheses are also developed on each construct as they relate to waqf giving intention towards 
education sector. In the context of waqf, the TPB has been used by many waqf researchers (Osman, Mohammed, \& Amin, 2014; Hasbullah, Khairi, \& Aziz, 2016; Shukor, Anwar, Aziz, \& Sabri, 2017; Zabri \& Mohammed, 2018) and found that the TPB can explain waqf giving intention behavior. They concluded that TPB constructs could predict the intention of waqf giving behavior toward education sector.

\section{Intention}

No doubt, the intention is an important element for accepting or rejecting one's behavior. Previous research studies are of the view that the predictor of behavior is the intention to behave (Saad \& Haniffa, 2014) . The behavioral intention of an individual is the cognitive representation of a person's willingness to implement a given behavior (Ajzen and Fishbein, 1975). Qardawi (2009) asserted that in Islam any worship without intention will not be rewarded. In the field of waqf, several studies have been conducted on an intention to giving behavior (Osman, Mohammed, \& Amin, 2014; Hasbullah, Khairi, \& Aziz, 2016; Shukor, Anwar, Aziz, \& Sabri, 2017; Thaker, Thaker, \& Pitchay, 2018).

\section{attitude}

Attitude is one of the factors showing that it does affect a person's intention to do something, and in response to this, the researchers have examined various aspects that can shape the attitude. Eagly \& Chaiken (1993) argue that attitude is a psychological tendency which is shown in the evaluation on certain entities with some degree of favor or disfavor. The attitude construct could be decomposed to offer greater understanding and predictive power of the construct (Farouk, Idris, \& Saad, 2018). Based on a wide range of studies in different settings of behaviors and intentions to engage in those behaviors, attitude explains over $50 \%$ of the variance in intentions (Ajzen, 1991). The more positive the attitude; the greater is the intention. According to Ajzen and Fishbein (1980), behavioral intentions are influenced significantly by attitude. Ajzen (1991) concluded that attitude toward a behavior is a major factor that influences intention apart from the subjective norm and perceived behavioral control. Furthermore, Ramayah, Rouibah, Gopi, \& Rangel (2009) also asserted that attitude toward a behavior is the main contributing factor of behavioral intention. In the context of waqf giving behavior, Hasbullah (2016) and Shukor (2017) confirmed that attitude significantly influences intention to give waqf. Despite several researchers who believe attitude is a predictor of intention to give waqf, there are some scholars in the waqf field who are of the view that attitude may not be a sufficient factor that can influence the decision of an individual to give waqf. For instance, Osman (2016) argued that attitude does not influence toward cash waqf giving intention. Although attitude has been studied in many fields (such as Islamic banking, tax Compliance behavioral intention, zakat, and cash waqf), attitude toward waqf giving behavioral intention for education sector is yet to be studied, especially in Kuwait. It is an important variable that needs to be studied because when an individual perceives important to direct waqf to education sector, it is likely that he or she will have a positive attitude toward intention to give waqf to education sector.

H1: There is a significant relationship between attitude, and waqif /endower's intention to funding waqf-based education. 


\section{Subjective norms}

Subjective norm is regarded as one's views of another person's feelings as to perform or not to perform a given behavior (Ajzen, 1991). In the context of waqf behavior, Osman (2016) and Hasbullah (2016) found that subjective norm significantly influences intention to cash waqf participation. Nevertheless, Osman, Ma'in, \& Muda (2019) confirmed that there is no relationship between subjective norm and intention to participate in green investment. Similarly, Huda, Rini, Mardoni, \& Putra (2012) mentioned that subjective norm does not influence zakat compliance behavior. Due to the inconsistent findings regarding this linkage and taking into consideration the absence of empirical studies on this relationship in cash waqf giving behavior setting, it is hypothesized that.

H2: There is a significant relationship between subjective norms, and waqif /endower's intention to funding waqf-based education.

\section{Perceived behavioral control}

Perceived behavioral control is defined as the belief a person has on factors that can influence his or her performance, internally or externally (Ajzen, 1991). Perceived behavioral control in this study refers to donor's intention of the degree to which they have control or can give waqf to education sector. In the perspective of waqf, Osman (2016) confirmed that perceived behavioral control significantly influences the intention to participate in cash waqf. Additionally, Osman (2019) found that perceived behavioral control is a strong predictor of intention to invest in the green investment. On the other hand, Hasbullah (2016) stated that perceived behavioral control does not effect on behavioral intention to contribute in corporate waqf. Matching with that, Khalifa \& Shen (2008) found that the effect of perceived behavioral control is found to be insignificant on the behavioral intention. There seems to be inconsistent results regarding this linkage. Thus, it is hypothesized that.

H3: There is a significant relationship between perceived behavioral control, and waqif /endower's intention to funding waqf-based education.

\section{Research Model}

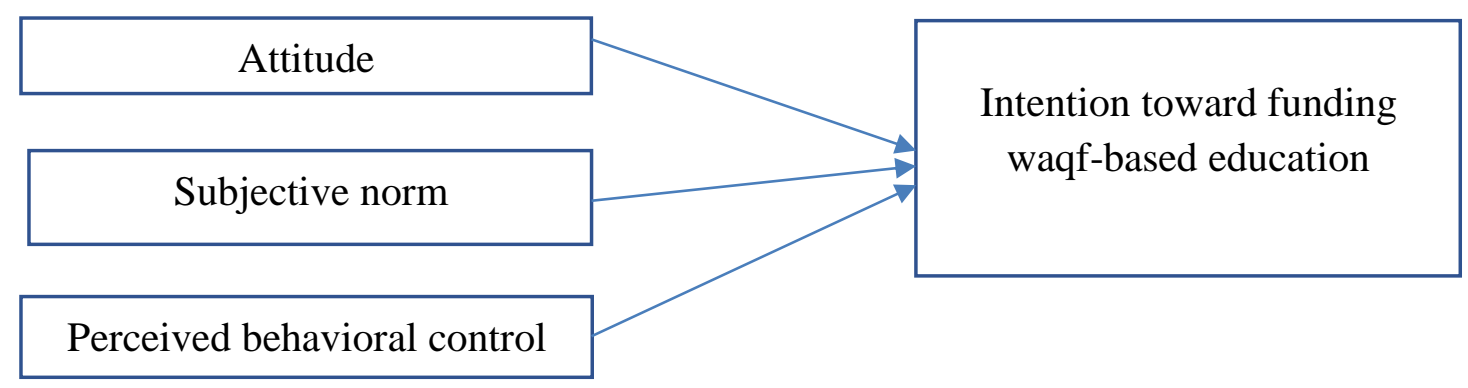

\section{Research methodology}

This research has used a quantitative approach by using survey form. The study method was tailored from previous research based on TPB. Utilizing proven measurements improves the reliability of the instruments used and prevents the tremendous time and work that would be invested in measurements development. Straub (1989) additional proposed that developing the existing and proven scales allows upcoming contrast with another research. In the questionnaire, the respondents were indispensable to rate their degree of agreement with 
statements and/or propositions on a 5-point Likert Scale, ranging from ' 1 ' representing 'strongly disagree' to ' 5 ' representing 'strongly agree'. The final measures are shown in Table 1.

\begin{tabular}{c|ccc}
\hline \multirow{2}{*}{ Measurement } & \multicolumn{2}{|c|}{ Questionnaire } & \multirow{2}{*}{ Sources } \\
\cline { 2 - 3 } & Number of questions & $\begin{array}{c}\text { Total of } \\
\text { items }\end{array}$ & \\
\hline Demographic profile & $1-5$ & 5 & Self-structured \\
\hline Independent Variables & $6-10$ & 5 & Shukor 2017 \\
\hline Attitude & $11-15$ & 5 & $\begin{array}{c}\text { Saad and Haniffa, } \\
2014\end{array}$ \\
\hline Subjective Norm & $16-19$ & 5 & $\begin{array}{c}\text { Smith \& } \\
\text { (2007) }\end{array}$ \\
\hline $\begin{array}{c}\text { Perceived Behavioral Control } \\
\text { Dependent Variable }\end{array}$ & & & \\
\hline $\begin{array}{c}\text { Intention of waqf giving } \\
\text { behaviors toward education } \\
\text { sector }\end{array}$ & $20-24$ & 5 & $\begin{array}{c}\text { Husbulla et al. } \\
(2016)\end{array}$ \\
\hline
\end{tabular}

This study was conducted at KAPF as it is the only government institution that responsible of waqf affairs in Kuwait. The employees of KAPF were chosen to be suitable to the objective of the study. This is because they are expected to be aware and familiar with the waqf practices as well as they can set example for others to be a part of waqf's contributions toward education sector. Besides, these employees can play role in the enactment of waqf rules and practice which established the commission responsible for managing waqf in Kuwait, KAPF. The population of this study is 345 employees work at KAPF (REFERNCE). A total of 300 questionnaires were distributed among the target sample using random sampling technique and 222 responses were returned with response rate of $74 \%$, while 212 responses were valid for further analysis. The response rate of the study is well adequate for analysis in light of the suggestion of Barbie (2007).

The study using (SPSS) version 25 to conduct frequency analysis, descriptive analysis, reliability, and multiple regressions' analysis. Frequency analysis is used to extract the percentile of the profiles of respondents in terms of gender, age, level of education, and years of experience. Mean and standard deviation are computed for descriptive analysis. The reliability test is used to examine the internal consistency among the items in their respective factors. The multiple regression analysis is particularly used to test the hypotheses proposed earlier.

\section{Findings}

Table 4.3 shows that the preponderance among 212 respondents goes to male with 95 (44.8\%) and female $117(55.2 \%)$. education level, most of the respondents are in bachelor level with $135(63.7 \%)$. Followed by diploma degree holders with $57(26.9 \%)$. While Master and $\mathrm{PhD}$ are $15(7.1 \%)$ and $5(2.4 \%)$ receptively. majority of the respondents are between the age of 20-30 years (37.3\%) and of $70(33 \%)$ represented the category of 31- 40 years old. While the respondents between 41-50 are 49 (23.1). Finally, 51-60 represent the minority with $13(6.1$ $\%)$. Furthermore, years of experience in the work in the Kuwait Awqaf public foundation were as follows, the majority were having fewer years of experience less than 5 years with 70 (33\%) 
followed by 5-9 years and 10-14 years with same respondents with 41 (19.3\%). While the respondents had 15 years and above of experience with 60 (28.3\%). Most of the respondents have general knowledge with 186 (87.7\%). About 14 (6.6\%) of respondents have Professional certificates in Islamic finance. Followed by $12(5.7 \%)$ respondents having academic certificates in Islamic finance.

Table 2: Respondents' Profile

\begin{tabular}{|c|c|c|c|}
\hline Variable & Characteristics & Number & $\begin{array}{c}\text { Percentage } \\
(\%)\end{array}$ \\
\hline \multirow{2}{*}{ Gender } & Male & 95 & 44.8 \\
\hline & Female & 117 & 55.2 \\
\hline \multirow{4}{*}{ Level of Education } & Diploma & 57 & 26.9 \\
\hline & Bachelor & 135 & 63.7 \\
\hline & Master & 15 & 7.1 \\
\hline & $\mathrm{PhD}$ & 5 & 2.4 \\
\hline \multirow{4}{*}{ Age } & $20-30$ & 80 & 37.7 \\
\hline & $31-40$ & 70 & 33 \\
\hline & $41-50$ & 49 & 23.1 \\
\hline & $51-60$ & 13 & 6.1 \\
\hline \multirow{4}{*}{ Years of experience in the (KAPF) } & Less than 5 years & 70 & 33 \\
\hline & 5- 9 years & 41 & 19.3 \\
\hline & $10-14$ years & 41 & 19.3 \\
\hline & 15 years and above & 60 & 28.3 \\
\hline \multirow{4}{*}{ Background of Islamic finance } & Academic certificates & & \\
\hline & Professional & 12 & 5.7 \\
\hline & certificates & 14 & 6.6 \\
\hline & General knowledge & 186 & 87.7 \\
\hline Total & & 212 & $100 \%$ \\
\hline
\end{tabular}

presented the minimum, maximum, means, and standard deviation of the model variables. The means values for the variables range between 3.3 and 3.8 The mean value of the variables indicates moderate scores of the agreement. The highest mean value is 3.8660 for the attitude independent variable, followed by the dependent variable wqaf contribution behaviour with a mean value of 3.6953, Perceived control behavior with a mean value of 3.5292 While subjective norm variable the mean value was 3.3642 . The standard deviation values are .91609 , $.89871, .85045$, and.77751 where it shows a moderate level showed that the variability of respondents in answering the questionnaire. If the value deviation is small, therefore the responses in a sample distribution of number fall very close to mean (Hair, Money, \& Page, 2007). 
Table 3: Descriptive Analysis

\begin{tabular}{lcccc}
\hline Variables & Minimum & Maximum & Mean & $\begin{array}{c}\text { Std. } \\
\text { deviation }\end{array}$ \\
\hline Contribution behavior & 1.00 & 5.00 & 3.6953 & .91609 \\
Attitude & 1.00 & 5.00 & 3.8660 & .77751 \\
Subjective norm & 1.00 & 5.00 & 3.3642 & .85045 \\
Perceived control behavior & 1.00 & 5.00 & 3.5292 & .89871 \\
\hline
\end{tabular}

Nnormality test was sought to confirm that all data has been distributed in normal shape. The normal distribution is especially crucial matter because it supplies a strong foundation for many of the deduction the gathered data using sampling. Table 4.1 display that the data utilized in this study is valid and did not break the normality presumption for the inferential analysis.

Table 4: Normality Test

\begin{tabular}{lcc}
\hline \multicolumn{1}{c}{ Variable } & Skewness & Kurtosis \\
\hline Waqf Contribution behavior & -.812 & .711 \\
Attitude & -.298 & -.058 \\
Subjective norm & -.395 & -.067 \\
Perceived control behavior & -.656 & .086 \\
\hline
\end{tabular}

Table illustrates the result of reliability test, whereby the Cronbach's alpha reliability coefficient was obtained for all the variables. In this study, the value of reliability analysis in Table 4.4 shows that Cronbach's alpha value is more than 0.7 the result shows Cronbach's alpha range between .749 until 0.848 . The values presented that Cronbach's alpha of this study for contribution, attitude, subjective norm, and perceived control behaviour are more than 0.70 and 0.80 . Thus, the strength is considered acceptable. As a result, the variable used in this study is consistent and steady.

Table 5: Reliability Test

\begin{tabular}{lcc}
\hline \multicolumn{1}{c}{ Variables } & Number of Items & Cronbach's Alpha \\
\hline Contribution behavior & 5 & .848 \\
Attitude & 5 & .749 \\
Subjective norm & 5 & .749 \\
Perceived control behavior & 5 & .805 \\
\hline
\end{tabular}

Table 4.7 below indicates the result of the correlation between all independent variables with the dependent variable. The Pearson correlation between variables are 0.000 which is significant at 0.05 . The significant value of attitude is 0.000 . thus, the hypothesis $\mathrm{H} 1$ has been statistically proved and it is positively accepted. For the next factor, Pearson correlation between subjective norms and behaviour indicate the relationship is significant with a value of 0.000 . therefore, hypothesis $\mathrm{H} 2$ have been statistically supported and it is positively accepted. Lastly Pearson correlation between perceived control behaviour and behaviour indicate the relationship is significant with a value of 0.000 . therefore, hypothesis $\mathrm{H} 3$ have been statistically supported and it's positively accepted. Therefore, from the results TPB theory has been approved as a theory can be provide theoretical to understand and expect human behaviour. 
Table 6: Correlations test

\begin{tabular}{lc}
\hline \multicolumn{1}{c}{ Variables } & Pearson Correlation \\
\hline Attitude & 0.000 \\
Subjective norm & 0.000 \\
Perceived control behavior & 0.000 \\
\hline
\end{tabular}

**. Correlation is significant at 0.05 level (2-tailed)

table 4.8 illustrates the regression analysis results through the coefficients table. Attitude is significantly associated with people's intention to contribute to the education sector by waqf $(\mathrm{t}$ $=8.408, \mathrm{p}=0.00, \beta=0.430$ ). Hence, $\mathrm{H} 1$ is supported. It also shows that subjective norm is significantly related to people's intention to contribute to the education sector by waqf $(\mathrm{t}=$ $3.806, \mathrm{p}=0.00, \mathrm{~B}=0.210$ ). Thus, $\mathrm{H} 2$ is supported. Lastly, perceived behavioral control is significantly related to people's intention to contribute to the education sector by waqf $(\mathrm{t}=$ 9.321, $\mathrm{p}=0.00, \mathrm{~B}=0.460$ ), and therefore $\mathrm{H} 3$ is supported.

Table 7: regression analysis

\begin{tabular}{llccc}
\hline Hypotheses & Beta & t-value & p-value & Supported? \\
\hline H1: There is a significant relationship & 0.430 & 8.408 & 0.000 & Yes \\
between attitude, and waqif /endower's & & & & \\
intention to endow to education sector. & & &
\end{tabular}

$\begin{array}{lllll}\text { H2: } \text { There is a significant relationship } & 0.210 & 3.806 & 0.000 & \text { Yes }\end{array}$

between subjective norms, and waqif /

endower's intention to endow to

education sector.

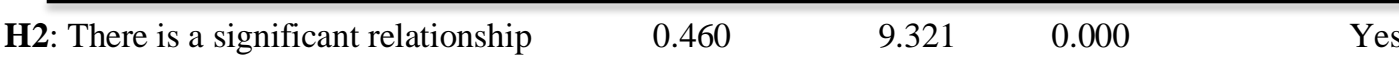

Between subjective norms, and waqif /

endower's intention to endow to

education sector.

R-square

0.759

Adjusted R-squared

0.755

Note: $* *$ significant at 5 percent, $*$ significant at 10 percent

\section{DISCUSSION AND IMPLICATIONS}

The findings of this study expressively augment the literature on waqf giving behavior by extending the theoretical model for examining people's attitudes toward online donation. In accommodating the contradictory viewpoints on whether the theory of planned behavior is applicable in a newly context of waqf, and in acknowledgement to proposals by prior research ( (Hasbullah, Khairi, \& Aziz, 2016; Osman, Mohammed, \& Amin, 2014; Shukor, Anwar, Aziz, \& Sabri, 2017). This issue yet has been furnished inadequate consideration by 
those who have solicitude in the field. In opposite, this issue is shown by the existing study with a view to propose novel perspicacity into the grasp of waqf allocation for education purposes in Kuwait. The results endorse the views of Osman, Mohammed, \& Amin (2014) and Hasbullah, Khairi, \& Aziz (2016) that among the three constructs of the TPB model. This study contributes into consumer behavior in different levels:

1. Theoretical implications: The application of the TPB in waqf was different in term of the context of the type of waqf, country, and population previously examined notwithstanding, findings were consistent with Osman, Mohammed, \& Amin (2014) and Hasbullah, Khairi, \& Aziz (2016), where the current study covers immovable and movable waqf in the connection of its allocation for education matters.

2. Policy implications: According to the outcome of this research, the (KAPF) as a (mutawalli) need to be conscious that the Kuwaiti donors have the intention to give and allocate waqf to education sector. Given a major role of (KAPF) in the developing waqf affairs, it demands develop a powerful scheme for incessant and collaborative endeavor to promote Muslims to have robust determination to grant waqf for education sector. For example, setting up campaigns in the social media platforms which would give publicity and knowledge about the role of waqf in the education sector which in turn is unavoidable to the Muslim community's development. Further, the (KAPF) ought to also establish extra workshops, discourses and lectures, in order to enhance the knowledge and awareness of Muslims about Maqasid Al-shariah behind giving waqf and eventually motivate them to customize waqf with social economic development, which education, no doubt, one of the most important.

\section{CONCLUSION}

This research is a pioneering study in assessing factors causing the accessibility of waqf in Kuwait. It presents innovative insights into the awareness of waqf giving behavior to education sector among Muslim donors. Additionally, the research expands the using of the theory of planned behavior in a different field, such as the waqf in Kuwait. The results demonstrate that factors examined are significant in describing waqf giving behavior toward education in Kuwait. According to these results, the (KAPF) and related governments agencies or policy makers can establish additional appropriate policies or fundraising strategies to encourage waqf giving behavior toward education sector among Muslims in Kuwait. Furthermore, the psychical factors pinpointed, which determine waqf giving behavior to education sector, emphasize methods in which (KAPF) can boost the amounts of waqf collection for education sector.

As for limitations, firstly, the geographical location of the research is limited to Kuwait, meaning that the results cannot be generalized to other Muslim countries that differ in philosophy and geography. Secondly, the research is based on finite population of illustrative factors. At Present, attitude, subjective norm, perceived behavioral control and intention are studied, whereas further factors which could influence giving behavior have not been considered yet. Future research may conduct in different Muslim communities to see how their willingness to participate in waqf giving toward education sector. Moreover, various potential factors for example trustworthiness, religiosity, and knowledge could offer valuable insights in the waqf giving behavior for education sector. 


\section{REFERENCES}

Ajzen , I. (1985). From Intentions to Actions: A Theory of Planned Behavior. In B. J. Kuhl J., SSSP Springer Series in Social Psychology. Berlin: Springer, Berlin, Heidelberg.

Ajzen, I. (2011). The theory of planned behaviour: Reactions and reflections. Psychology and Health, 1113-1127.

Ajzen, I., \& Fishbein, M. (1975). A Bayesian Analysis of Attribution Processes. Psychological Bulletin, 261-277.

Ajzen, I., \& Fishbein, M. (1977). Attitude-Behavior Relations: A Theoretical Analysis and Review of Empirical Research. Psychological Bulletin, 888-918.

Alelyan, A. (2019, May 6). The Problem With Kuwait's Higher Education. Retrieved from ARABIA HIGHER ED: http://www.arabiahighered.com/index.php/home-news/allnews/139-kuwait/657-the-problem-with-kuwait-s-higher-education

Eagly, A. H., \& Chaiken, S. (1993). The psychology of attitudes. Harcourt Brace Jovanovich College Publishers.

Farouk, A. U., Idris, K. M., \& Saad, R. A. (2018). Determinants of Attitude Towards Zakat on Employment Income in Nigeria. International Journal of Banking and Finance, 29-48.

Hair, J. H., Money, A. H., \& Page, P. M. (2007). Research Methods for Business. Education + Training, 336-337.

Hasbullah, N. A., Khairi, K. F., \& Aziz, M. A. (2016). INTENTION TO CONTRIBUTE IN CORPORATE WAQF: APPLYING THE THEORY OF PLANNED BEHAVIOUR. International Journal of Islamic and Civilizational Studies, $39-48$.

Higher education between the challenges of reality and the aspirations of the future. (2019, March 13). Retrieved from ALANBA: https://www.alanba.com.kw/ar/kuwaitnews/431724/22-12-2013-

Huda, N., Rini, N., Mardoni, Y., \& Putra, P. (2012). The Analysis of Attitudes, Subjective Norms, and Behavioral Control on Muzakki's Intention to Pay Zakah. International Journal of Business and Social Science, 271-279.

Investment Opportunities in Kuwait through KDIPA. (2018, January 10). Retrieved from KUWAIT DIRECT INVESTMENT PROMOTION AUTHORITY: https://www.kdipa.gov.kw/en/investments-2/

Khaf, M. (1999). Financing the development of awqaf property. American Journal of Islamic Social Sciences, 39-68.

KHALIFA, M., \& SHEN, K. N. (2008). DRIVERS FOR TRANSACTIONAL B2C MCOMMERCE ADOPTION : EXTENDED THEORY OF PLANNED BEHAVIOR. Journal of Computer Information Systems, 111-117.

Kuwait Vision 2035 "New Kuwait". (2018, May 12). Retrieved from Ministry of Foreign Affairs : https://www.mofa.gov.kw/en/kuwait-state/kuwait-vision-2035/

Mahamood, S., \& Ab Rahman, A. (2015). Financing universities through waqf, pious endowment: is it possible? Humanomics, 430 - 453.

Osman, A. F., Mohammed, M. O., \& Amin, H. (2014). AN ANALYSIS OF CASH WAQF PARTICIPATION AMONG YOUNG. 9th International Academic Conference (pp. 711723). Istanbul,: International Institute of Social and Economic Sciences, Czech Republic. 
Osman, I., Ma'in, M., \& Muda, R. (2019). DETERMINANTS OF BEHAVIOURAL INTENTION TOWARDS GREEN INVESTMENTS: THE PERSPECTIVES OF MUSLIMS. International Journal of Islamic Business, 16-38.

Predicting dishonest actions using the theory of planned behavior . (1991). Journal of Research in Personality, 285-301.

Qardawi, Y. (2009). Fiqh al Zakat: A Comparative Study of Zakah, Regulation and Philosophy in the Light of Qur'an and Sunnah. Jeddah: Scientific Publishing Centre King Abdulaziz University.

Ramayah, T., Rouibah, K., Gopi, M., \& Rangel, G. J. (2009). A decomposed theory of reasoned action to explain intention to use Internet stock trading among Malaysian investors. Computers in Human Behavior, 1222-1230.

Saad , R. J., \& Haniffa , R. (2014). Determinants of zakah (Islamic tax) compliance behavior. Journal of Islamic Accounting and Business Research, 182-193.

Sachs, J. D. (2015). Achieving the Sustainable Development Goals. Journal of International Business Ethics, 53-62.

Shukor, S. A., Anwar, I. F., Aziz, S. A., \& Sabri, H. (2017). MUSLIM ATTITUDE TOWARDS PARTICIPATION IN CASH WAQF: ANTECEDENTS AND CONSEQUENCES AND CONSEQUENCES. International Journal of Business and Society, 193-204.

Thaker, M. M., Thaker, H. M., \& Pitchay, A. A. (2018). Modeling crowdfunders'behavioral intention to adopt the crowdfunding-waqf model (CWM) in Malaysia The theory of the technology acceptance model. International Journal of Islamic and Middle Eastern Finance and Management, 231-249.

The Economic Challenges Facing Kuwait and the Region. (2019, January 5). Retrieved from CEF:

https://www.cef.imf.org/content/cef/home/Events/The_Economic_Challenges_Facing_ Kuwait_and_the_Region.html

Zabri, M. Z., \& Mohammed, M. O. (2018). Examining the behavioral intention to participate in a Cash Waqf-Financial Cooperative-Musharakah Mutanaqisah home financing model. Managerial Finance, 809-829

Zuki, M. M. (2012). WAQF AND ITS ROLE IN SOCIOECONOMIC DEVELOPMENT. ISRA International Journal of Islamic Finance , 173-178. 